\title{
Structure versus Culture: $A$ Comparative Study of the Influence of Political Institutions and Cultural Modernization Factors on Voter Turnout in Swiss Sub-national Parliamentary Elections
}

\author{
Markus Freitag
}

\begin{abstract}
How can the differing levels of voter participation in sub-national parliamentary elections be explained? To answer this question I start from the current literature on cross-national comparative research, and apply explanatory approaches from this literature to the analysis of electoral turnout in sub-national units. I focus on two competing influential assessments in the literature, institutionalism and cultural modernization. The first assumes that formal political institutions generate important incentives and habits that are capable of shaping and constraining voting behavior. In contrast, a cultural modernization approach predicts that crosssectional differences in turnout are determined by cultural habits arising from the socialization process and societal modernization. The systematic examination of electoral democracy in the Swiss cantons shows that the differing rates of electoral participation in these sub-national units are primarily attributable to the strength of political Catholicism. In this vein, rather than differences in turnout being a function of institutional and electoral procedures, they reflect cultural norms in the Swiss cantons. Moreover, the findings suggest that cultural conditions may be more significant for electoral behavior on a sub-national than on an international level.
\end{abstract}

\section{Keywords}

Catholicism, elections, sub-national comparative method, voter turnout, Swiss cantons

\section{Introduction}

This contribution deals with a central question in comparative political sociology (Lijphart, 1997): how can the differing levels of voter participation in parliamentary elections be explained?

Corresponding author:

Markus Freitag, University of Konstanz, Department of Politics and Management, PO Box 84, D-78457 Konstanz,

Germany

[email: markus.freitag@uni-konstanz.de] 
Existing empirical work remains inconclusive regarding the key determinants of electoral participation (Blais, 2006; Geys, 2006; Norris, 2004). ${ }^{1}$ In the literature, one can distinguish two alternative approaches, institutionalism and cultural modernization. The first approach assumes that formal political institutions generate important incentives and habits that are capable of shaping and constraining voting behavior (Jackman and Miller, 1995). The alternative approach claims that cross-sectional differences in turnout are determined by cultural habits, e.g. deep-seated and habitual patterns of behavior arising from the socialization process and societal modernization (Inglehart, 1990; Norris, 2004). This controversy provides the starting point for the present examination.

Contrary to the prevailing investigative practice, I intend to study this topic by analyzing subnational units, i.e. the Swiss cantons, rather than on an international comparative scale. At least two reasons suggest an empirically based examination of this topic. First, in light of the political, cultural and socioeconomic diversity of the Swiss cantons (Freitag, 2000, 2004, 2006; Kriesi et al., 1996; Meier-Dallach and Nef, 1987), the Swiss 'laboratory' provides an unusual opportunity in which to assess the competing explanatory approaches of comparative electoral participation research, and to supplement existing research practice - unilaterally geared toward international comparison - with sub-national insights. Second, the Swiss Federal State, with its more than two dozen cantonal units, offers unusual methodological advantages: although the Swiss cantons reflect a multitude of political, societal and economic structures, they are components of a unitary and superordinate system (Vatter, 2002). In this sense, sub-national comparisons are particularly wellsuited to the most-similar cases design (Lijphart, 1971: 168; Snyder, 2001). Moreover, the cantonal democracies provide a sufficiently high number of investigative units for a statistical-quantitative research design (Vatter, 2002: 2).

In this article I focus on variations in levels of cantonal parliamentary voter turnout in 23 Swiss cantons between 1982 and 2005. The investigation excludes the cantons Appenzell Inner Rhodes, Appenzell Outer Rhodes and Grisons, since no data concerning levels of participation in cantonal parliamentary elections are available for these units. Starting with the first polls following the founding elections of the canton Jura (1978), the research period is intended to cover both current developments and a sufficiently long investigative time span in order to minimize possible distortions caused by short-term fluctuations. Thus, the analysis incorporates four to six ballots. $^{2}$

The macro-level investigation aims to assess the impact of institutional as well as cultural determinants on the differences in levels of cantonal electoral participation. Hypotheses put forward by - hitherto underdeveloped - empirical research on voter participation in cantonal parliamentary elections share assumptions that have been developed and examined for the - considerably better researched - international level (Linder, 2005: 67-68; Wernli, 1998). Thus, it seems prudent to begin from current cross-national comparative research and to apply these explanatory approaches to an analysis of sub-national units.

A systematic comparative examination of electoral democracy in the Swiss cantons reveals that the differing rates of electoral participation in these sub-national units are primarily attributable to the strength of political Catholicism. Therefore, rather than levels of voter turnout reflecting institutional and electoral procedures, they reflect cultural norms in the Swiss cantons. These results could provide the impetus for comparative (sub-national) research that goes beyond the Swiss context, as the political science literature on voter turnout tends to concentrate on institutional factors and largely ignores cultural or religious conditions. Investigations of these factors exist only at 
the individual level; analyses of aggregate data focusing on the influence of religious affiliation are almost nonexistent (Blais, 2006; Driskell et al., 2008: 294; Geys, 2006).

This study progresses along four steps. First, I identify the different levels of voter turnout in the Swiss cantons under consideration. Second, I discuss the competing theories and hypotheses. Third, I test the various hypotheses using bivariate and multivariate analyses. The article ends with conclusions.

\section{Dependent Variable}

In almost no other country do the individual states dispose of such far-reaching competences and rights of self-determination as the cantons in the Swiss Federation. Cantonal autonomy in the framework of the Federal Constitution and the cantons' equal rights, as well as their participation in federal decision-making and the duty to cooperate with the Federation and with each other, are regarded as the centerpieces of the Swiss political system. Switzerland is thus both a prime and an extreme example of a federal state. Although there are great similarities between the basic features of the Federation's and the cantons' political decision-making structures and processes, there are nevertheless significant institutional differences between the two federal levels (Linder, 2005; Vatter, 2002). For example, unlike the Federal Assembly, which consists of the National Council (Nationalrat) and Council of States (Ständerat), there is only one parliamentary chamber in the cantons.

With regard to voter turnout rates in parliamentary elections, there are striking differences between the Swiss cantons. Table 1 depicts average voter turnout in each canton during three time periods (1982-1991, 1992-2005 and 1982-2005). ${ }^{3}$ The data represents the number of votes cast as a percentage of eligible electors. As Table 1 shows, voter turnout differs substantially among cantons almost 40 percent between the cantons with the lowest and highest turnout. If one compares average turnout in 1992-2005 and 1982-1991, the cantons of Ticino, Valais, Schaffhausen and Jura display the highest electoral participation rates for both periods.

Between 1982 and 1991, Argovia and Vaud exhibit the lowest turnout. In the later period, BaselCountry and Berne have the lowest rates of participation. Between 1982 and 1991, 11 cantons reveal turnout above 50 percent; this is only the case for six cantons in the following period. Electoral participation declines in nearly all cantons. Comparing participation rates in the two periods, Jura (-11.3 percentage points), Lucerne (-9.6), and Schaffhausen $(-9.5)$ display the strongest rates of decline. In contrast, eligible voters in Uri (7.3), Basel-Town (2.5), and Argovia (0.6) exhibit an increasing willingness to participate. Looking at the variation coefficients of the two measurement periods 1982-1991 and 1992-2005, the differences between cantons remain almost unchanged over time.

An analysis of the electoral participation rates between 1982 and 2005 provides the following picture: in the first group of cantons, consisting of Ticino, Valais, Schaffhausen and Jura, average electoral participation exceeded 60 percent. In the second group, comprising Lucerne, Solothurn and Nidwalden, voter turnout exceeded 50 percent. A third group, consisting of Zug, Obwalden, Glarus, Fribourg and Uri, had an average turnout between 45 and 50 percent. The numerically largest group (Basel-Town, Neuchâtel, Schwyz, St Gall, Zurich, Argovia, Thurgovia and Geneva) comprises the cantons with a voter turnout of around 40 percent. A fifth and final group had an average electoral participation rate around 35 percent. This group comprises Basel-Country, Berne and Vaud. These data demonstrate that there are cantons with strongly declining as well as increasing electoral participation rates; it is also obvious that there were marked and consistent 
Table I. Electoral Participation in Cantonal Parliamentary Elections, 1982-2005

\begin{tabular}{llll}
\hline & $1982-1991$ & $1992-2005$ & $1982-2005$ \\
\hline Ticino & 72.0 & 68.2 & 69.8 \\
Valais & 66.1 & 63.1 & 64.3 \\
Schaffhausen & 68.3 & 58.8 & 63.2 \\
Jura & 68.1 & 56.8 & 61.7 \\
Lucerne & 59.9 & 50.3 & 54.5 \\
Solothurn & 57.3 & 49.9 & 53.0 \\
Nidwalden & 55.3 & 52.0 & 53.4 \\
Zug & 54.5 & 47.5 & 50.6 \\
Obwalden & 52.9 & 47.7 & 49.9 \\
Glarus & 54.0 & 45.7 & 49.3 \\
Fribourg & 52.8 & 44.2 & 48.0 \\
Uri & 41.1 & 48.4 & 45.0 \\
Basel-Town & 41.0 & 43.5 & 42.4 \\
Neuchâtel & 43.7 & 40.1 & 41.6 \\
Schwyz & 42.2 & 39.9 & 40.9 \\
St Gall & 41.8 & 39.1 & 40.3 \\
Zurich & 41.5 & 37.9 & 39.4 \\
Argovia & 38.2 & 38.8 & 38.6 \\
Thurgovia & 43.1 & 34.9 & 38.6 \\
Geneva & 39.6 & 37.5 & 38.3 \\
Basel-Country & 40.6 & 32.3 & 35.9 \\
Berne & 39.0 & 32.9 & 35.6 \\
Vaud & 34.0 & 33.4 & 33.7 \\
Average & 49.9 & 45.3 & 47.3 \\
Variation coefficient & 22.3 & 21.5 & 21.6 \\
\hline
\end{tabular}

Note:The table depicts the average values for the period stated. Electoral participation is measured in terms of the proportion of citizens eligible to vote who actually voted.

differences in turnout rates among Swiss cantons between 1982 and 2005 . How can these differences be explained?

\section{Theoretical Overview and Derivation of Hypotheses}

Comparative research has long sought to understand the reasons for electoral participation and to find explanations for cross-sectional differences in turnout. Two research directions - a politicoinstitutional perspective and the cultural modernization approach - dominate the debate. Thus far, institutional variables have proven particularly influential (Franklin, 1996, 2004; Geys, 2006; Jackman and Miller, 1995; Norris, 2004). In this section, I describe these theoretical perspectives and identify the hypotheses they generate concerning determinants of differences in cantonal voter turnout. In attempting to explain and interpret the effect of a macro-variable on electoral participation, previous studies primarily rely on models that have mainly been developed to explain the electoral behavior of individuals, i.e. the socio-structural and socio-psychological perspective or the rational choice approach (Bühlmann et al., 2003: 34-35). Similarly, the present investigation takes hypotheses concerning individual determining factors, perceptions, and motives for voting into account. 


\section{Politico-institutional Determinants}

In existing comparative electoral participation research, by far the most attention is paid to politico-institutional determinants (Lijphart, 1997: 7). Reflecting the tradition of neo-institutionalism, this approach conceives of institutions as the 'rules of the game,' which facilitate certain actions while preventing others. In other words: institutions, in this view, function equally as formalized rules and as social norms that facilitate, limit or stimulate individual attitudes and actions (Hall and Taylor, 1996). Macro-quantitative research generally distinguishes between politico-institutional conditions in the broader sense and factors concerning electoral law and administration (Norris, 2004: 153). While characteristics of the electoral system, the party system and government structures belong to the former set of conditions, organizational factors, such as electoral laws, polling day, voting procedures (e.g. by absentee ballot) or compulsory voting requirements, are part of the second category. ${ }^{4}$ Advocates of the institutional research perspective generally look for institutional arrangements which coincide with participation in an election (Blais and Dobrzynska, 1998; Jackman and Miller, 1995: 469; Norris, 2004; Schaffer, 2002). ${ }^{5}$

\section{Electoral System}

Relevant research identifies the type of electoral system as a variable explaining differences in electoral participation levels; a key distinction is made between proportional representation and majority voting (Milner and Ladner, 2006; Siaroff and Merer, 2002). Majoritarian electoral systems are seen to impose barriers to high electoral participation since elections are not controversial in safe constituencies or strongholds, and supporters of the previously defeated party or small parties abstain because they consider their vote to be ineffective. Moreover, previously defeated parties reduce their mobilization efforts. Electoral systems can be further characterized by the degree of disproportionality between vote and mandate share. The smaller the disparity, the more 'fairly' a party's share of votes is converted into the number of seats it is awarded. Disproportional electoral systems force smaller parties to obtain a disproportionately large number of votes in order to attain a certain (albeit disproportionately low) level of parliamentary representation. This leads to electoral abstention by supporters of disadvantaged political coalitions: the higher the degree of disproportionality, the lower the turnout (Jackman and Miller, 1995: 470). The most important factors affecting the degree of proportionality are constituency size and the existence of thresholds (Vatter, 2002). These two hallmarks can, moreover, be subsumed in the effective electoral threshold (Vatter, 2002: 396). ${ }^{6}$ This threshold indicates the percentage of votes a party must obtain in order to be represented in parliament. The higher the threshold, the more powerfully demobilization mechanisms affect voters and parties, and thus the lower is electoral participation. Further parameters of the electoral system are the possibility for parties to combine electoral lists and the possibilities to accumulate votes. The existence of both features can be assessed as a voting incentive for supporters of otherwise disadvantaged political groupings, and should result in higher electoral participation.

\section{Party System}

In their search for the forces driving participation rates, researchers frequently refer to the competitive situation within the party system (Blais and Dobrzynska, 1998: 249; Kostadinova, 
2003; Wernli, 1998). This perspective assumes that while elections with pre-determined outcomes make for a certain apathy and ignorance among voters, strong party competition has a stimulating effect. At the same time, it is claimed that the weight of the individual vote increases with the supposed closeness of an electoral outcome. In other words: the more an individual vote may influence the electoral result, the more citizens are likely to go to the polls. Furthermore, the number of parties is assumed to have an effect on electoral participation. The more fragmented a party system, the more multi-faceted the party-ideological spectrum becomes, and thus the more possibilities the voter has to find a party in which she sees her interests represented (Blais and Dobrzynska, 1998: 248). Thus, party diversity is said to boost motivation to participate in elections. ${ }^{7}$ Finally, a high level of electoral participation may result from a polarized party system, since opposing party camps have a greater capacity to entice their respective clientele (Crepaz, 1990; Norris, 2004: 167).

\section{Government Features}

A comparison of the Swiss cantons offers a great benefit for comparative electoral research in that one can quantitatively measure the impact of direct democratic instruments on electoral participation. Two competing assessments can be formulated regarding the influence of direct democracy on participation in cantonal parliamentary elections. The first conjecture assumes that a culture of active referendum democracy stimulates citizens' political interest, renders the flow of information quasi-independent, and thus also supports electoral democracy (Hajnal and Lewis, 2003). Wernli (1998), for instance, reaches this conclusion in his comparison of 10 Swiss cantons. He finds that electoral participation is higher in cantons where a more intensive form of direct democracy is practiced. The opposite hypothesis predicts a negative relationship between direct democracy and electoral democracy. There are two reasons why this might be the case: first, sundry popular initiatives and referenda restrict the competencies of government, parliament, and parties. As a result, the voter believes that she is in a position to decide authoritatively on important issues, independently and without recourse to members of parliament. From this perspective, policies are decided primarily in referenda and not during (less relevant) elections (Bühlmann et al., 2003; Linder, 2005: 320-323). Second, where there are several pillars of political co-determination, it is conceivable that weariness could develop regarding elections and referenda, which would affect less significant ballots (Jackman and Miller, 1995: 483). Beyond the effect of referendum democracy, cantons with well-developed local autonomy could be expected to ascribe little importance to cantonal authorities. Given their limited powers of action and decision, elections to a cantonal parliament would thus be considered largely irrelevant.

\section{Electoral Law}

Among the factors concerning electoral law and administration, compulsory voting is particularly significant when explaining electoral participation (Lijphart, 1997). At the international level, Italy and the Netherlands pursued this arrangement until 1993 and 1970, respectively. Today, compulsory voting continues to exist, for instance, in Australia, Belgium, Brazil, Bulgaria, Costa Rica, Greece, Luxemburg, Liechtenstein, Mexico, Peru, Singapore, Turkey and Cyprus. Among the Swiss cantons, compulsory voting exists only in Schaffhausen. Here, citizens can be driven to vote by the threat of retroactive penalties. ${ }^{8}$ In accordance with participation theory, regular participation, 
institutionally regimented, in the democratic process leads to the acquisition of political competence and to the development of an active political interest (Pateman, 1970). With regard to Switzerland, the citizens of Schaffhausen demonstrate a relatively high level of political interest and information (Wernli, 1998: 91). According to these previous research conclusions, compulsory voting leads us to expect a higher rate of turnout (Franklin, 2004).

\section{Cultural Modernization Determinants}

In general, the cultural modernization perspective argues that people's responses to their situations are shaped by subjective orientations that vary across and within cultures. These variations reflect differences in one's socialization experience, with early learning conditioning later learning. Following this line of thought, action cannot be interpreted as simply the result of external (political) situations: enduring differences in cultural and modernization learning play an important part in shaping what people think and do (Inglehart, 1990: 19). Moreover, deepseated configurations of norms and habits passed from generation to generation may persist unaltered. With regard to electoral participation, cultural accounts suggest that electors are influenced by their socioeconomic resources and their political attitudes, beliefs, and values, generating habitual and deeply rooted patterns of participation, so that mass political behavior will respond only sluggishly, if at all, to changes in political institutions (Norris, 2004: 176). Accordingly, other investigations attribute an influence on the level of electoral participation not only to primarily institutional factors on the aggregate data level, but also to cultural and modernization factors (Blais, 2006; Crepaz, 1990; Gray and Caul, 2000; Norris 2004; Siaroff and Merer, 2002).

\section{Socio-political Integration}

At least since De Tocqueville's (1835[1994]) analyses, social science has been dealing with the significance of voluntary associations for the social and political integration of societies. In modern social science this perspective's fundamental ideas can be traced back to the politicocultural research of the 1960s, where voluntary organizations are considered 'the most important foundations' of stable democracies, and secure the latter's continued existence (Almond and Verba, 1965: 220-222). Here, voluntary organizations act not only as mediums of political socialization, but also as 'schools for democracy,' since they enable the 'membership role' to be combined with the 'role of citizen' in social practice. Dedicated members of associations are better informed about political issues, show a higher degree of political interest, and, as a rule, are also more politically active than non-members. According to these basic considerations, willingness to participate in elections increases with the degree of an individual's involvement in organizational networks. This is thought to apply particularly to members of political organizations. At any rate, corresponding survey data and analyses prove that members of a trade union organization are more likely to participate in elections than citizens not involved in a trade union (Falter and Schumann, 1994: 176-178; Gray and Caul, 2000; Norris, 2004: 173-175). Translating the results concerning trade union members into the comparative macro-perspective, I derive the following hypotheses: cantons with a high density of trade union membership can be expected to demonstrate a high level of electoral participation. Cantons with a low organizational density should display a low rate of participation. Existing research also attributes particular significance to partisan membership as a mobilization motor: 'the propensity to participate 
or abstain is a habit of the heart acquired early in life and reinforced through experience of successive elections, along with other closely related civic attitudes and values such as partisan attachments' (Norris, 2004: 154). In other words: the higher a canton's density with regard to party members and thus the stronger the societal penetration of politics, the stronger the effect of party mobilization and the greater the willingness to participate in cantonal elections should be. Accordingly, party members have an increased incentive to vote, since by doing so they see their interests represented and realized. We know from empirical electoral research that the likelihood of electoral turnout increases with the increasing degree of party affiliation (Bühlmann et al., 2003; Falter and Schumann, 1994: 199; Norris, 2004: 156; Wernli, 1998: 86-87). Assuming that party membership can be understood as an expression of party identification, the insights gained from surveys should, in principle, be transferable in terms of the expected effect of the variable 'party membership.'

\section{Politico-cultural Characteristics}

A key variable for political participation is political interest: a person who is politically interested will participate in elections more than someone who is politically uninterested. An increasing level of political interest corresponds to increasing individual awareness of political issues and personal involvement in the political sphere. Consequently, an interested person will tend to vote more frequently than a politically uninterested person (Bühlmann et al., 2003; Wernli, 1998). Cantons with a high density of politically interested citizens therefore ought to demonstrate higher turnout rates than sub-national units with a low proportion of politically interested citizens. Finally, in the Swiss context, Catholicism is traditionally considered a significant, historically established politico-cultural driving force behind electoral participation. According to Wernli (1998: 96-98), there is a particularly strong bond in the Swiss cantons between the Christian Democratic Party (CVP) and the Catholics. This historically entrenched relationship dates back to the defeat of the Catholic coalition at the end of the Sonderbundkrieg (short Swiss civil war, 1847). In the aftermath of this war, the Catholic population grew to perceive itself as a minority subordinated to worldly and modernizing forces, and withdrew into a kind of isolated society in the strongholds of the Catholic cantons (Altermatt, 1989; Geser, 2004; Linder, 2005: 36-40). In these cantons, federal order guaranteed the continuation of Catholic morals and customs. It is thought that in cantons with a Catholic majority (such as Valais, Lucerne and Ticino), elections are perceived as regular threats to the bastion of Catholicism and essential Christian religious values. This perception, together with the clientelistic entanglements between party and ideology, is thought to act as a mobilizing force for electoral participation. In view of the enduring confessionalpolitical culture in Switzerland (Geser, 2004), these ties may also affect contemporary developments. In other words, Catholicism is thought to exert a propulsive effect on political participation. ${ }^{9}$ There are of course additional reasons as to why Catholicism would bolster participation (Driskell et al., 2008; Jones-Correa and Leal, 2001): first, religiosity, and especially Catholicism, continues to be a central variable in electoral research. Above all, religious Catholics tend to have close ties to conservative parties, something that is also expressed in their actual electoral participation, as they want their own party to be successful and win votes. In Germany, for example, this close connection can be explained historically in terms of the culture struggle and the minority role that Catholics once played. Second, as a particularly collectivist religion, Catholicism, unlike the more individual-oriented Protestantism, 
should also promote more collective forms of political participation. The Catholic tendency to vote (collective act) should thus be greater than that of writing a letter to one's representative (individual act), for example. Third, Catholicism continues to be an expression of traditionalism and conformity. For this reason, conventional forms of political participation (elections) should be preferred to unconventional types of political participation (demonstrations, protests, etc.) in a Catholic context. Fourth, the widely known and well-researched higher church attendance of Catholics, in particular, should also be a decisive factor for voter turnout. Through this strong structural integration of its adherents, Catholicism has a greater mobilization potential - originating in the existing flow of information and expressed by a strong belief in the social desirability of voting.

Within the cultural modernization perspective, some comparative contributions refer to the effect of socioeconomic and socio-demographic factors on voter turnout rates (Radcliff, 1992). Education, economic strength, population density and age patterns among eligible voters are mentioned as particularly relevant influencing variables (Blais and Dobrzynska, 1998: 241244; Norris, 2004; Siaroff and Merer, 2002: 917). Where existing research draws upon societies' cognitive and material resources to explain varying electoral participation rates, it refers primarily to differing levels of education and economic strength (Sturm, 1992: 491). According to the standard model of political participation, greater personal resources lead to the formation of positive attitudes toward the political system, strengthen political interest and bestow the feeling that one's potential participation will be politically effective (Verba and Nie, 1972: 125-137). A high level of resources thus results in increased participation (Bühlmann et al., 2003: 27). Where there are fewer resources, converse relationships can be observed. At the aggregate level this means that the higher a democracy's level of socioeconomic development or degree of modernity, the higher the rate of electoral participation will be (Blais and Dobrzynska, 1998: 241-244; Siaroff and Merer, 2002). ${ }^{10}$ Regarding population density and population size, researchers assume that less densely populated areas will have lower turnout, since a scattered population is more difficult to mobilize and relevant information is less accessible (Blais and Dobrzynska, 1998: 242-243).

\section{Method, Data and Operationalizations}

The systematic empirical examination of the hypotheses focuses on the period between 1982 and 2005. The objects of empirical analysis are all Swiss cantons, with the exception of Appenzell Inner Rhodes, Appenzell Outer Rhodes and Grisons, since no data concerning levels of participation in cantonal parliamentary elections are available for these units. To test the assumed relations, I conducted a frequently used two-step procedure (see in detail, Armingeon, 2002; Vatter, 2002). First, bivariate analyses are performed for each of the explaining variables, followed by multiple regression analyses (ordinary least squares technique), which only include the variables found to have the highest explanatory power in the first step (Tables $2-4)$. The variables included in the multivariate model are those resulting from the specification search: first, bivariate regression analyses were performed to identify independent variables that would be most likely to be significant in multiple regression models. Variables with non-significant coefficients were eliminated. There is a chance that the insignificant correlations could become significant in a multivariate model; however, considering that the critical level of significance has been set rather low $(p \leq 0.05)$, further multivariate improvements of the basic model are not very promising. Being interested in strong and robust relations, I find 
this radical bivariate strategy is appropriate. Moreover, the multiple regression analyses contain five variables at most (including the constant), which should not cause severe problems with regard to the degrees of freedom. Finally, in adopting this approach, I aim to safeguard assumptions made on the basis of the first step through the findings of further quantitative analytical techniques in order to distinguish statistically serious relationships from possible spurious correlations. The bivariate and multivariate cross-sectional analyses are based on the mean values of the individual variables.

The dependent variable is the cantonal level of electoral participation by eligible voters (see Table 1, column 4). The appendix provides an overview of the explanatory variables derived from the individual theories as well as their operationalizations. With regard to the operationalizations, I address the fundamental ideas of the politico-institutional circumstances perspective in terms of compulsory voting, the type of electoral system, the degree of disproportionality, the effective electoral threshold, the possibility to combine electoral lists and to accumulate votes, the party system's degree of competition, polarization and fractionalization, direct democratic participation rights, and the degree of local autonomy. ${ }^{11}$

For the cultural and modernization forces perspective, I examine the respective cantonal population shares of associational membership, party and trade union membership, and Catholics. I also include aspects of political interest. Finally, I control for the proportion of secondary enrolment, the proportion of Matura graduates (Matura = secondary school diploma enabling admission to university), cantonal per capita GDP, an index of financial resources, the inhabitants per square kilometer and the population size of a canton. ${ }^{12}$

\section{Results}

The results of the bivariate analyses (Table 2) can be summarized as follows: initially, three of 11 politico-institutional conditions have a statistically significant influence on the level of voter turnout. As found in international comparative studies, compulsory voting also boosts the level of electoral participation. While the canton of Schaffhausen, with its compulsory voting, reached an average participation rate of 63.2 percent in the investigation period, average turnout in the other cantons was only 46.6 percent. It should, however, be mentioned that compulsory voting is by no means a substantial explanatory factor in a comparison of the Swiss cantons. The proportion of non-voters amounts to nearly 40 percent even in the canton of Schaffhausen. Moreover, Ticino and Valais have higher average parliamentary election turnouts. While the type of electoral system, the possibilities of combining electoral lists and of accumulating votes, and the effective electoral threshold fail to have any statistically significant effect on cantonal electoral participation according to the criterion $(p \leq 0.05)$, the sign of the degree of disproportionality points in the theoretically expected direction: the more disproportional the manner in which an electoral system converts votes into mandates, and the higher the proportion of votes required to attain parliamentary representation, the lower the voter turnout in cantonal elections.

Concerning the party system, neither the degree of competitiveness nor its degree of polarization has a systematic effect on electoral participation. Although the influence of the degree of fractionalization is statistically significant, the sign of the coefficient does not point in the theoretically expected direction: the more fractionalized a party system is (i.e. the larger the number of parties), the lower the voter turnout. One could conclude that a high number of party alternatives confuses voters, imposes high information costs and ultimately discourages them from voting 
Table 2. Determinants of Electoral Participation in Cantonal Parliamentary Elections 1982-2005, Bivariate Regressions

\begin{tabular}{|c|c|c|}
\hline \multirow[t]{2}{*}{ Independent variables (average values for each canton 1982-2005) } & \multicolumn{2}{|l|}{ Cantons $(N=23)$} \\
\hline & $\begin{array}{l}\text { Unstandardized } \\
\text { regression } \\
\text { coefficients }\end{array}$ & Absolute $t$-value \\
\hline \multicolumn{3}{|l|}{ Politico-institutional determinants } \\
\hline Compulsory voting (dummy: yes $=\mathrm{I}$ ) & 16.43 & 7.64 \\
\hline Electoral system (proportional representation system $=1$ ) & -1.44 & 0.32 \\
\hline Degree of disproportionality of the electoral system & -4.63 & 2.51 \\
\hline Effective electoral threshold & -0.74 & 1.66 \\
\hline Combination of electoral lists (dummy: yes $=1$ ) & -2.24 & 0.43 \\
\hline Accumulation of votes (dummy: yes $=1$ ) & -1.60 & 0.32 \\
\hline Degree of competition of the party system & 0.15 & 0.60 \\
\hline Degree of fractionalization of the party system & -43.26 & 2.36 \\
\hline Degree of polarization of the party system & -2.24 & 1.91 \\
\hline Direct democracy (index) & 0.16 & 0.08 \\
\hline Degree of local autonomy & 2.35 & 1.18 \\
\hline \multicolumn{3}{|l|}{ Cultural modernization factors } \\
\hline Proportion of associational memberships & -0.05 & 0.13 \\
\hline Proportion of party members & 3.62 & 3.70 \\
\hline Proportion of trade union members & 0.61 & 0.94 \\
\hline Political interest & -0.19 & 0.58 \\
\hline Proportion of Catholics & 0.25 & 2.71 \\
\hline Ratio of secondary enrolment & -0.55 & 1.12 \\
\hline Quota of Matura graduates & 4.30 & 0.10 \\
\hline Per capita GDP (log.) & -14.57 & 1.52 \\
\hline Financial resources & -0.07 & 1.48 \\
\hline Population density (inhabitants per $\mathrm{km}^{2}$ ) (log.) & -3.66 & 2.50 \\
\hline Size of cantonal population (log.) & -3.95 & 2.91 \\
\hline
\end{tabular}

Notes: Boldfaced type indicates the statistically significant correlations that are situated below the 5 percent level; absolute $t$-values are calculated using the procedure of corrected standard errors according to White $(1980)$. The correlations were calculated without Appenzell Inner Rhodes, Appenzell Outer Rhodes and Grisons, since no data on electoral participation rates are available for these cantons. For the canton Uri, it was not possible to calculate a degree of disproportionality due to missing percentages of votes. Accordingly, only 22 cantons were included in the calculations here. The table in the Appendix provides an overview of the operationalization of the individual variables.

(Kostadinova, 2003: 754). Finally, according to the estimates, neither the degree of local autonomy nor referendum democracy has an effect on voter turnout.

The cultural modernization perspective is endorsed by a total of four of the 11 influencing factors examined here: the larger the proportion of party members and Catholics in a canton, the higher the level of the cantonal voter turnout. Population density is also relevant; however, contrary to theoretical expectations, high levels of electoral participation are more likely in less densely populated cantons. Another finding that runs contrary to theoretical expectations is that a large cantonal population increases the likelihood of lower turnout. These are the central results of the 
Table 3. Determinants of Electoral Participation in Cantonal Parliamentary Elections 1982-2005, Multiple Regressions

\begin{tabular}{|c|c|c|c|c|}
\hline Variable & Model I & Model 2 & Model 3 & Model 4 \\
\hline Constants & 97.93 & 13.35 & -13.99 & 17.44 \\
\hline Compulsory voting & $\begin{array}{l}16.30 \\
(4.94) * *\end{array}$ & $\begin{array}{l}23.27 \\
(5.39)^{* * *}\end{array}$ & $\begin{array}{l}23.60 \\
(12.14) * *\end{array}$ & $\begin{array}{l}23.08 \\
(12.79) * *\end{array}$ \\
\hline $\begin{array}{l}\text { Degree of disproportionality of the electoral } \\
\text { system }\end{array}$ & $\begin{array}{l}-3.40 \\
(1.57)\end{array}$ & & & \\
\hline Fractionalization of the party system & $\begin{array}{l}-55.77 \\
(2.24)^{*}\end{array}$ & & $\begin{array}{l}31.87 \\
(1.09)\end{array}$ & \\
\hline Proportion of party members & & 2.16 & 2.42 & 2.05 \\
\hline Proportion of Catholics & & $\begin{array}{l}(2.39) * \\
0.28 \\
(2.68)^{*}\end{array}$ & $\begin{array}{l}(2.36)^{*} \\
0.36 \\
(3.04)^{* *}\end{array}$ & $\begin{array}{l}(2.57)^{*} \\
0.27 \\
(3.67)^{* * *}\end{array}$ \\
\hline Population density (inhabitants per $\mathrm{km}^{2}$ ) (log.) & & $\begin{array}{l}0.45 \\
(0.32)\end{array}$ & & \\
\hline Size of cantonal population (log.) & & $\begin{array}{l}0.02 \\
(0.01)\end{array}$ & & \\
\hline $\begin{array}{l}R^{2} \\
\text { Number of observations }\end{array}$ & $\begin{array}{l}0.46 \\
22\end{array}$ & 23 & $\begin{array}{l}0.66 \\
23\end{array}$ & $\begin{array}{l}0.63 \\
23\end{array}$ \\
\hline
\end{tabular}

Notes: For the operationalization of the individual variables, see the text and table in the Appendix. The table depicts the unstandardized regression coefficients; ${ }^{*}=$ significant on the 5 percent level (two-tailed test); ${ }^{* *}=$ significant on the I percent level (two-tailed test); absolute $t$-values in parentheses (calculated using the procedure of corrected standard errors according to White [1980]). It was not possible to calculate a disproportionality degree for the canton Uri due to missing percentages of votes. Accordingly, only 22 cantons were included in the calculations in Model I.

analysis of the second set of variables. All other assumed influential variables fail to show the expected propulsive effect.

In a next step, I include those factors that have proven significant in the bivariate analyses in a multivariate test. I first estimate four cross-sectional regressions (models 1 to 4 ). As there are many influential variables and only a limited number of cases, I cannot simultaneously include all influential variables in a single multivariate model. For this reason, model 1 contains only the politicoinstitutional factors. Model 2 comprises the significant cultural modernization factors. Finally, models 3 and 4 contain the significant influencing variables from the respective previous estimates. Compulsory voting is included in all models. The results of the further examinations are as follows: first, when controlling for other factors, population density, population size, degree of disproportionality of the electoral system and the fragmentation of the party system fail to reach significance in explaining the varying levels of cantonal voter turnout. ${ }^{13}$ Second, the multivariate models confirm the influence of compulsory voting, Catholicism, and the density of partisan membership on cantonal turnout rates in parliamentary elections. Third, model 4 - which is based on a simple equation of all significant variables - is capable of explaining 63 percent of the variance in cantonal voter turnout.

The results of model 4 indeed require further testing. Since I am dealing with a very small number of cases, individual units can exert a significant influence on the estimation of the parameters. 
Table 4. Multiple Regression Diagnostics on Model 4, from Table 3

\begin{tabular}{|c|c|c|c|c|c|}
\hline Variable & $\begin{array}{l}\text { Model } 5 \\
\text { (robust } \\
\text { standard } \\
\text { errors hc3) }\end{array}$ & $\begin{array}{l}\text { Model } 6 \\
\text { (robust } \\
\text { regression) }\end{array}$ & $\begin{array}{l}\text { Model } 7 \\
\text { (bootstrapping } \\
1000 \text { reps) }\end{array}$ & $\begin{array}{l}\text { Model } 8 \\
\text { (jackknife) }\end{array}$ & $\begin{array}{l}\text { Model } 9 \\
\text { (without } \\
\text { Schaffhausen and } \\
\text { robust standard } \\
\text { errors hc3) }\end{array}$ \\
\hline $\begin{array}{l}\text { Constants } \\
\text { Compulsory voting }\end{array}$ & $\begin{array}{l}17.44 \\
23.09 \\
(2.79)^{* *}\end{array}$ & $\begin{array}{l}16.02 \\
23.87 \\
(2.55) * *\end{array}$ & $\begin{array}{l}15.31 \\
24.60 \\
(2.10)^{* *}\end{array}$ & $\begin{array}{l}17.44 \\
23.09 \\
(1.04)\end{array}$ & 17.44 \\
\hline $\begin{array}{l}\text { Proportion of party } \\
\text { members } \\
\text { Proportion of Catholics }\end{array}$ & $\begin{array}{l}2.04 \\
(2.31)^{*} \\
0.27 \\
(3.41)^{* *}\end{array}$ & $\begin{array}{l}2.15 \\
(1.60) \\
0.26 \\
(2.80)^{* *}\end{array}$ & $\begin{array}{l}2.13 \\
(1.59) \\
0.27 \\
(2.98)^{* *}\end{array}$ & $\begin{array}{l}2.04 \\
(2.36) \\
0.27 \\
(3.49)^{* *}\end{array}$ & $\begin{array}{l}2.04 * \\
(2.31) \\
0.27 \\
(3.41)^{* *}\end{array}$ \\
\hline Number of observations & 23 & 23 & 23 & 23 & 22 \\
\hline
\end{tabular}

Notes: For the operationalization of the individual variables, see the text and table in the Appendix. The table depicts the unstandardized regression coefficients; ${ }^{*}=$ significant on the 5 percent level (two-tailed test); ${ }^{* *}=$ significant on the I percent level (two-tailed test); absolute $t$-values in parentheses.

Particularly in small samples, there is a risk that the obtained results might be dominated by a few observations, thereby casting doubt on the reliability of a regression estimate and the resulting conclusions (see Table 4).

The first multivariate model uses the test statistic he3, which is based on White's (1980) procedure for estimating consistent standard errors in the presence of heteroskedastic residuals and is particularly suited for small samples (model 5). Regarding the hypothesized effects of the three independent variables on turnout, the estimated coefficients are similar to those of default model 4. In order to estimate the strength of influential data points, the calculated estimates for models 6 to 9 are based on various common approaches found in the existing literature. One possibility to reduce the effect of outliers is to enter the sum of the squared residuals into a function that places less weight on larger residuals. This is achieved with robust regression (model 6). Bootstrap re-sampling treats the sample as a population and re-samples the residuals with replacement a specified number of times (model 7). With the jackknife technique, the same model is calculated for different sub-samples, wherein the sample is always continuously reduced by exactly one observation (model 8). The results of models $6-8$ show that the initial positive and significant effect of Catholicism remains unchanged; the proportion of party members (models 6 and 7) as well as compulsory voting (model 8), however, become insignificant. Furthermore, calculating leverage values reveals the canton of Schaffhausen as a relevant case (model 9). All other cases proved to be unproblematic for the analysis. The estimation of model 9 without Schaffhausen does not, however, alter the results in any way, although the exclusion of this canton also constitutes the exclusion of compulsory voting from the analysis as an explanatory factor. In sum, robustness analyses show that cantonal voter turnout is positively and significantly related only to the proportion of Catholics in a canton in all tests. By contrast, the significant results regarding compulsory voting and partisan membership in the default model 4 are not robust. ${ }^{14}$ In light of the significance level and the variety of regression diagnostics conducted, I am confident of the results presented here. 


\section{Conclusion}

In this article I have evaluated institutional and cultural modernization arguments by comparing electoral turnout rates in the Swiss cantons between 1982 and 2005. The main result is the robust positive and significant relationship between Catholicism and voter turnout. In other words, above average participation in cantonal elections can be found in those sub-national units that are strongly Catholic. Cantons with a low proportion of Catholics lead us to predict a comparatively low level of voter turnout. In this way, the regional analysis corroborates the cultural modernization hypothesis. Moreover, I have shown that the variation in the turnout rates is not directly linked to institutional features. In contrast to the theoretical predictions and findings of several other cross-national studies, the analyses fail to provide support for the hypothesis that characteristics of the electoral system, the party system, and government structure influence voter turnout at the sub-national level. Furthermore, the analyses show that compulsory voting is by no means a necessary or robust condition for high electoral turnout in the Swiss cantons: for one, it exists only in the canton of Schaffhausen. In addition, the fact that nearly 40 percent of Schaffhausen's population do not vote demonstrates that the abstention penalty of $€ 2$ is not compelling enough to bring citizens to the polls. The conclusions about the impact of institutions align with Blais' (2006: 116) recent verdict: he argues that the perception that cross-national differences in turnout can be explained by institutional variations may in fact not be a well-founded one.

Moreover, the findings regarding the cultural foundations could be of general significance for at least three reasons: First and foremost, due to its cultural, religious, and regional diversity, the late Stein Rokkan called Switzerland a microcosm of Europe (Linder, 1994: xii). Accordingly, Rokkan recommended that anyone wishing to study the dynamics of European politics and society should immerse him- or herself in the study of Switzerland. Second, this investigation provides support for the argument that different forces of political participation work at different governmental levels (Blais, 2006: 117). It is precisely in these smaller and more manageable communities that social networks play a significant role for voter mobilization (Blais, 2006: 117). The Catholic outlook is of particular importance here. The environment of the Catholic Church not only imparts an active interest in community welfare, but also offers historically determined and non-denominational opportunity structures for social and political participation in which space, personnel, and a variety of opportunities for various activities are provided (Offe and Fuchs, 2001: 445). Catholic-dominated outlooks may therefore serve as a catalyst for collective social and political action. This hypothesis is also relevant for further sub-national electoral studies. Third, culturally and religiously established patterns of behavior can always play a role when participation rates vary despite the presence of very similar institutional structures across the (sub-national) units of analysis. In this vein, one could envision sub-national units that, due to centralization tendencies, have nearly identical politico-institutional configurations and are subject to a federal-state convergence process, or sub-national units whose political characteristics have, over the course of decentralization and regionalization, yet to fully develop (for example, the regions of France, Poland and the Czech Republic). The extent to which differences are recognizable, in both the output and outcomes of such political subsystems, could be an indication of different and historically bequeathed regional cultures.

In light of the results of internationally comparative electoral participation research, the present findings suggest that cultural conditions are more significant for electoral behavior at the subnational than at the national level. Furthermore, it is important to distinguish between culture and institution; with respect to sub-national research, however, the competition between the two concepts is far from over. 
Appendix I. Variables, Hypotheses and Operationalizations

\begin{tabular}{|c|c|c|c|}
\hline Variable & Hypothesis (ceteris paribus) & Operationalization/source & Expected relationship \\
\hline \multicolumn{4}{|c|}{ Politico-institutional determinants } \\
\hline Compulsory voting & $\begin{array}{l}\text { Compulsory voting increases participation in } \\
\text { cantonal elections }\end{array}$ & $\begin{array}{l}\text { Dummy variable (I = compulsory voting, } \\
\text { only in canton of Schaffhausen). }\end{array}$ & Positive \\
\hline Electoral system & $\begin{array}{l}\text { Proportional representation systems lead to } \\
\text { higher participation in cantonal elections }\end{array}$ & $\begin{array}{l}\text { Dummy variable (I = pure proportional } \\
\text { representation). Source: Lutz and Strohmann } \\
(1998: 80) \text {. }\end{array}$ & Positive \\
\hline $\begin{array}{l}\text { Disproportionality of the } \\
\text { electoral system }\end{array}$ & $\begin{array}{l}\text { The higher an electoral system's degree of } \\
\text { disproportionality, the lower the participation in } \\
\text { cantonal elections }\end{array}$ & $\begin{array}{l}\text { Measured according to index by Gallagher } \\
\text { (199I). Own calculations based on Ladner } \\
\text { (2004) and own updates. }\end{array}$ & Negative \\
\hline $\begin{array}{l}\text { Effective electoral } \\
\text { threshold }\end{array}$ & $\begin{array}{l}\text { The higher the effective electoral threshold, the } \\
\text { lower the participation in cantonal elections }\end{array}$ & $\begin{array}{l}\text { Effective electoral threshold following Lijphart } \\
\text { (1999: 153) = 75/average number of mandates } \\
\text { per constituency plus I. Source:Vatter (2002). }\end{array}$ & Negative \\
\hline $\begin{array}{l}\text { Combination of electoral } \\
\text { lists }\end{array}$ & $\begin{array}{l}\text { The possibility to combine electoral lists increases } \\
\text { participation in cantonal elections }\end{array}$ & $\begin{array}{l}\text { Dummy variable ( } I=\text { combination of electoral } \\
\text { lists possible). Source: Lutz and Strohmann } \\
\text { (1998: 72). }\end{array}$ & Positive \\
\hline Accumulation of votes & $\begin{array}{l}\text { The possibility to accumulate votes increases } \\
\text { participation in cantonal elections }\end{array}$ & $\begin{array}{l}\text { Dummy variable (I = accumulation of votes } \\
\text { possible). Source: Lutz and Strohmann } \\
\text { (1998: 78) }\end{array}$ & Positive \\
\hline $\begin{array}{l}\text { Degree of competition of } \\
\text { the party system }\end{array}$ & $\begin{array}{l}\text { The more intense the competition in a cantonal } \\
\text { party system, the higher the participation in } \\
\text { cantonal elections }\end{array}$ & $\begin{array}{l}\text { Difference between two strongest parties' } \\
\text { numbers of mandates in a ballot. Source: own } \\
\text { calculations based on Ladner (2004). }\end{array}$ & Negative \\
\hline $\begin{array}{l}\text { Degree of fractionalization } \\
\text { of the party system }\end{array}$ & $\begin{array}{l}\text { The more fractionalized a cantonal party system, } \\
\text { the higher the participation in cantonal elections }\end{array}$ & $\begin{array}{l}\text { Fractionalization index following Rae (1968). } \\
\text { Source: own calculations based on Ladner } \\
\text { (2004). }\end{array}$ & Positive \\
\hline $\begin{array}{l}\text { Degree of polarization of } \\
\text { the party system }\end{array}$ & $\begin{array}{l}\text { The more polarized a cantonal party system, the } \\
\text { higher the participation in cantonal elections }\end{array}$ & $\begin{array}{l}\text { Polarization index based on self-assessment of } \\
\text { the cantonal party presidents. Source: Ladner } \\
\text { (2004). }\end{array}$ & Positive \\
\hline
\end{tabular}


Appendix I. (Continued)

\begin{tabular}{|c|c|c|c|}
\hline Variable & Hypothesis (ceteris paribus) & Operationalization/source & Expected relationship \\
\hline Direct democracy & $\begin{array}{l}\text { The more developed direct democratic popular } \\
\text { rights are, the lower the participation in cantonal } \\
\text { elections }\end{array}$ & $\begin{array}{l}\text { Index of direct democracy (values from I } \\
\text { (poorly developed direct democracy) to } 6 \\
\text { (strongly developed direct democracy)). } \\
\text { Source: Stutzer (1999). }\end{array}$ & Negative \\
\hline Degree of local autonomy & $\begin{array}{l}\text { The more decentralized decision-making structures } \\
\text { are in a canton, the lower the participation in } \\
\text { cantonal elections }\end{array}$ & $\begin{array}{l}\text { Index of municipal autonomy vis-à-vis the } \\
\text { Confederation and cantons following Ladner } \\
\text { (1994: } 81)(0=\text { no autonomy whatsoever; } \\
10=\text { very high degree of autonomy). }\end{array}$ & Negative \\
\hline \multicolumn{4}{|c|}{ Cultural modernization determinants } \\
\hline $\begin{array}{l}\text { Proportion of associational } \\
\text { memberships }\end{array}$ & $\begin{array}{l}\text { The larger the proportion of associational } \\
\text { membership in a canton, the higher the } \\
\text { participation in cantonal elections }\end{array}$ & $\begin{array}{l}\text { Proportion of individuals who state that } \\
\text { they are a member of at least one club or } \\
\text { organization. Source: own calculations based } \\
\text { on the Schweizerische Arbeitskräfteerhebung } \\
\text { (SAKE) 1997, 2000, } 2004 \text { (annual occupational } \\
\text { survey of the Swiss population conducted by } \\
\text { the Bundesamt fur Statistik). }\end{array}$ & Positive \\
\hline $\begin{array}{l}\text { Proportion of party } \\
\text { members }\end{array}$ & $\begin{array}{l}\text { The larger the proportion of party members in } \\
\text { a canton, the higher the participation in cantonal } \\
\text { elections }\end{array}$ & $\begin{array}{l}\text { Proportion of party members among eligible } \\
\text { voters in the 1990s. Source: own calculations } \\
\text { based on Ladner and Brändle (200I). }\end{array}$ & Positive \\
\hline $\begin{array}{l}\text { Proportion of trade union } \\
\text { members }\end{array}$ & $\begin{array}{l}\text { The larger the proportion of trade union members } \\
\text { in a canton, the higher the participation in cantonal } \\
\text { elections }\end{array}$ & $\begin{array}{l}\text { Trade union members as a percentage of the } \\
\text { population. Source: own calculations based on } \\
\text { the Schweizerischer Gewerkschaftsbund (pers. } \\
\text { corr.). }\end{array}$ & Positive \\
\hline Political interest & $\begin{array}{l}\text { The larger the proportion of politically interested } \\
\text { individuals in a canton, the higher the participation } \\
\text { in cantonal elections }\end{array}$ & $\begin{array}{l}\text { Proportion of individuals who, in } 2003 \text {, stated } \\
\text { that they were 'very interested' and 'fairly } \\
\text { interested' in cantonal political procedures. } \\
\text { Source: Swiss Electoral Studies (Selects) } 2004 .\end{array}$ & Positive \\
\hline Proportion of Catholics & $\begin{array}{l}\text { The larger the proportion of Catholics in a canton, } \\
\text { the higher the participation in cantonal elections }\end{array}$ & $\begin{array}{l}\text { Proportion of Catholics in the cantonal } \\
\text { population in the 1980s and I990s. Source: } \\
\text { Bundesamt für Statistik and Bovay and Broquet } \\
\text { (2004: I22-123). }\end{array}$ & Positive \\
\hline $\begin{array}{l}\text { Ratio of secondary } \\
\text { enrolment }\end{array}$ & $\begin{array}{l}\text { The higher the ratio of secondary enrolment, the } \\
\text { higher the participation in cantonal elections }\end{array}$ & $\begin{array}{l}\text { Proportion of secondary enrolment (1995). } \\
\text { Source: own calculations based on SAKE (1995). }\end{array}$ & Positive \\
\hline
\end{tabular}


Appendix I. (Continued)

\begin{tabular}{|c|c|c|c|}
\hline Variable & Hypothesis (ceteris paribus) & Operationalization/source & Expected relationship \\
\hline Quota of Matura graduates & $\begin{array}{l}\text { The higher the quota of Matura graduates, the } \\
\text { higher the participation in cantonal elections }\end{array}$ & $\begin{array}{l}\text { Number of Matura degrees issued in the } \\
\text { relevant year per number of } 19 \text {-year-olds in } \\
\text { the constant population, classed by parental } \\
\text { canton of residence. Source: Bundesamt für } \\
\text { Statistik. }\end{array}$ & Positive \\
\hline Per capita GDP (log.) & $\begin{array}{l}\text { The higher (lower) the level of economic } \\
\text { prosperity in a canton, the higher the participation } \\
\text { at cantonal elections }\end{array}$ & $\begin{array}{l}\text { Average per capita GDP. Own calculations } \\
\text { based on the cantons' national income. } \\
\text { Source: Bundesamt für Statistik (pers. corr. from } \\
\text { Caroline Le Bourdonnec). }\end{array}$ & Positive/negative \\
\hline Financial resources & $\begin{array}{l}\text { The higher (lower) the level of economic prosperity } \\
\text { in a canton, the higher the participation in cantonal } \\
\text { elections }\end{array}$ & $\begin{array}{l}\text { Index of financial strength as per Federal } \\
\text { Finance Administration (1990-2000, declared } \\
\text { every two years: } \mathrm{CH}=100) \text {. Source: } \\
\text { Staatssekretariat für Wirtschaft (SECO). }\end{array}$ & Positive/negative \\
\hline Population density (log.) & $\begin{array}{l}\text { The more densely populated a canton, the higher } \\
\text { the participation in cantonal elections }\end{array}$ & $\begin{array}{l}\text { Cantonal population per square kilometer. } \\
\text { Source: Staatssekretariat für Wirtschaft (SECO). }\end{array}$ & Positive \\
\hline $\begin{array}{l}\text { Size of the cantonal } \\
\text { population }\end{array}$ & $\begin{array}{l}\text { The higher the population size of a given canton, } \\
\text { the higher the participation in cantonal elections }\end{array}$ & $\begin{array}{l}\text { Size of cantonal population 1990. Source: } \\
\text { Bundesamt für Statistik. }\end{array}$ & Positive \\
\hline \multicolumn{4}{|l|}{ Dependent variable } \\
\hline Voter turnout & & $\begin{array}{l}\text { Proportion of citizens eligible to vote who } \\
\text { actually voted in a cantonal parliamentary } \\
\text { election 1982-2005. Source: Jahrbuch für } \\
\text { Schweizerische Politik (various volumes). }\end{array}$ & \\
\hline
\end{tabular}




\section{Notes}

1. Some of the information for this article was generously provided by Birgit Jacob, Jennifer Shore, Richard Traunmüller and Adrian Vatter. I am grateful to them and the anonymous referees for their thoughtful comments and suggestions.

2. In this way, I hope to mask out strong aberrations caused by particularly momentous historical events. In the democratic transition research, the early periods of statehood are considered to be 'moments of great drama,' accompanied by incomparable political, social and economic tensions (Kostadinova, 2003: 743). Of eligible voters 81.2 percent took part in the first elections of the newly-founded Jurassic parliament. Comparing the last 25 years of cantonal turnout, this level is quite unique: only 73.1 percent took part in the subsequent elections in 1982.

3. The entire period is added, since it provides the empirical basis for further analyses.

4. No prior registration is necessary in order to participate in cantonal elections.

5. While a rational choice account of the institutional perspective implies that institutions work through incentives, the historical-institutional perspective argues that institutions shape affective norms and habits through socialization mechanisms. Because the data do not differentiate between the rational choice and historical institutionalism arguments, both arguments are worth considering.

6. This barrier is calculated as follows: effective electoral threshold $=75 /$ (average number of mandates in a constituency plus 1). An example: a regional unit has three constituencies with three, four and five mandates. The effective electoral threshold is therefore 15 percent for each of the parties (Lijphart, 1999: 153). This kind of threshold can be interpreted as an implicit exclusion clause.

7. The literature also contains a competing outlook claiming that elections are less important in fragmented multi-party systems because the government tends to be formed through coalition agreements rather than by popular vote (Downs, 1957: 155). This hypothesis does not apply to the Swiss cantons, as cantonal governments are appointed via direct popular election.

8. See electoral law 160.11, article 9 of Schaffhausen's Code of Law: 'Participation in federal, cantonal and local referenda and elections, and in residents' municipal assemblies, is compulsory until the age of 65 . Any person who neglects this duty without an excuse shall be obliged to pay three francs.' According to the Schaffhausen State Chancellery, the respective municipalities determine this sum.

9. While Geser's (2004) analytical focus is mainly on recent developments, Lijphart (1979) shows that even in the 1970s, the confessional conflict in Switzerland was more significant than the differences between language groups and socio-economic strata.

10. It should be noted, however, that the modernization process can also occur at the expense of political participation via elections, since rising education and income standards are increasingly accompanied by unconventional forms of participation as more effective possibilities for political influence (Inglehart, 1990).

11. Some skepticism has been expressed regarding the inclusion of the variable 'compulsory voting.' This factor is nevertheless an institutional peculiarity of one of the units analyzed (Schaffhausen). Its omission would constitute a misspecification of the model and a failure to consider actual circumstances.

12. With regard to statistical analyses not reported here, there is no systematic statistical relationship between voter turnout and the language region (ratio of German-speaking persons to cantonal population). Moreover, the reported findings are not sensitive to the inclusion of the language variable. I am grateful to the referee for pointing this out.

13. Neither the population size nor the density in model 2 is significant when the other is omitted.

14. Additional multivariate estimations (not documented here) with variables that were eliminated over the course of the research confirmed the lack of significance of such variables. In addition to the diagnostics carried out here, I performed estimations with cluster-adjusted standard errors. 
These estimations support the present results. Additionally, I tested for multicollinearity and heteroskedasticity; again, these do not significantly influence the results. According to further statistical analyses not reported here, the positive impact of Catholicism holds, regardless of the time period (1982-1991 and 1992-2005).

\section{References}

Almond G and Verba S (1965) The Civic Culture: Political Attitudes and Democracy in Five Nations. Boston, MA: Little Brown.

Altermatt U (1989) Katholizismus und Moderne: Zur Sozial- und Mentalitätsgeschichte der Schweizer Katholiken im 19. und 20. Jahrhundert. Zürich: Benziger.

Armingeon K (2002) The effects of negotiation democracy. European Journal of Political Research 40: $81-105$.

Blais A (2006) What affects voter turnout? Annual Review of Political Science 9: 111-125.

Blais A and Dobrzynska A (1998) Turnout in electoral democracies. European Journal of Political Research 33: 239-261.

Bovay C and Broquet R (2004) Religionslandschaft in der Schweiz. Neuchâtel: Bundesamt für Statistik [Federal Statistical Office].

Bühlmann M, Freitag M and Vatter A (2003) Die schweigende Mehrheit: Eine Typologie der Schweizer Nichtwählerschaft. In: Sciarini P, Hardmeier S and Vatter A (eds) Schweizer Wahlen 1999, Swiss Electoral Studies Bd. 5. Bern: Paul Haupt, 27-58.

Crepaz MML (1990) The impact of party polarization and postmaterialism on voter turnout. A comparative study of 16 industrial democracies. European Journal of Political Research 18: 183-205.

Downs A (1957) An Economic Theory of Democracy. New York: Harper \& Row.

Driskell R, Embry E and Lyon L (2008) Faith and politics: the influence of religious beliefs on political participation. Social Science Quarterly 89(2): 294-314.

Falter JW and Schumann S (1994) Der Nichtwähler - das unbekannte Wesen. In: Kaase M and Klingemann H-D (eds) Wahlen und Wähler. Analysen aus Anlaß der Bundestagswahl 1990. Opladen: Westdeutscher Verlag, 161-213.

Franklin MN (1996) Electoral participation. In: LeDuc L, Niemi RG and Norris P (eds) Comparing Democracies: Elections and Voting in Global Perspective. Thousand Oaks, CA: Sage, 216-235.

Franklin MN (2004) Voter Turnout and the Dynamics of Electoral Competition in Established Democracies since 1945. Cambridge: Cambridge University Press.

Freitag M (2000) Soziales Kapital und Arbeitslosigkeit. Eine empirische Analyse zu den Schweizer Kantonen. Zeitschrift für Soziologie 29: 186-201.

Freitag M (2004) Schweizer Welten des Sozialkapitals. Empirische Untersuchungen zum sozialen Leben in Regionen und Kantonen. Schweizerische Zeitschrift für Politikwissenschaft 10: 87-118.

Freitag M (2006) Bowling the state back in: political institutions and the creation of social capital. European Journal of Political Research 45: 123-152.

Gallagher M (1991) Proportionality, disproportionality, and electoral systems. Electoral Studies 10(1): $33-51$.

Geser H (2004) Gibt es in der Schweiz noch konfessionelle politische Kulturen? Einige überraschende Befunde aus einer diachronen Studie über lokale Parteien. Zürich: Soziologisches Institut.

Geys B (2006) Explaining voter turnout: a review of aggregate-level research. Electoral Studies 25: 637-663.

Gray M and Caul M (2000) Declining voter turnout in advanced industrial democracies, 1950 to 1997. Comparative Political Studies 33: 1091-1122. 
Hajnal Z and Lewis PG (2003) Municipal institutions and voter turnout in local elections. Urban Affairs Review 38(5): 645-668.

Hall PA and Taylor RCR (1996) Political Science and the Three New Institutionalisms. Cologne: Max-Planck Institut für Gesellschaftsforschung.

Inglehart R (1990) Cultural Shift in Advanced Industrial Society. Princeton, NJ: Princeton University Press.

Jackman RW and Miller RA (1995) Voter turnout in the industrial democracies during the 1980s. Comparative Political Studies 27(4): 467-492.

Jahrbuch für Schweizerische Politik (various volumes) Universität Bern: Institut für Politikwissenschaft.

Jones-Correa MA and Leal DL (2001) Political participation: does religion matter? Political Research Quarterly 54(4): 751-770.

Kostadinova T (2003) Voter turnout dynamics in post-Communist Europe. European Journal of Political Research 42: 741-759.

Kriesi H, Wernli B, Sciarini P and Gianni M (1996) Le clivage linguistique. Problèmes de compréhension entre les communautés linguistiques en Suisse. Bern: Office fédéral de la statistique.

Ladner A (1994) Finanzkompetenzen der Gemeinden - ein Überblick über die Praxis. In: Eng F, Glatthard A and Koenig BH (eds) Finanzföderalismus. Zürich: Emissionszentrale der Schweizer Gemeinden, 64-85.

Ladner A (2004) Kantonale Parteiensysteme im Wandel. Eine Studie mit Daten der Wahlen in den Nationalrat und in die kantonalen Parlamente. Neuchâtel: Bundesamt für Statistik [Federal Statistical Office].

Ladner A and Brändle M (2001) Die politischen Parteien im Wandel. Von Mitgliederparteien zu professionalisierten Wählerorganisationen? Zürich: Seismo.

Lijphart A (1971) The comparable-cases strategy in comparative research. Comparative Political Studies 8: 158-177.

Lijphart A (1979) Religious vs. linguistic vs. class voting: the crucial experiment of comparing Belgium, Canada, South Africa and Switzerland. American Political Science Review 73: 442-458.

Lijphart A (1997) Unequal participation: democracy's unresolved dilemma. American Political Science Review 91(1): 1-14.

Lijphart A (1999) Patterns of Democracy. Government Forms and Performance in Thirty-Six Countries. New Haven, CT: Yale University Press.

Linder W (1994) Swiss Democracy. Possible Solutions to Conflict in Multicultural Societies. New York: St Martins Press.

Linder W (2005) Schweizerische Demokratie. Institutionen, Prozesse, Perspektiven. Bern: Paul Haupt.

Lutz G and Strohmann D (1998) Wahl- und Abstimmungsrecht in den Kantonen. Bern: Paul Haupt.

Meier-Dallach H-P and Nef R (1987) Values and identities in Switzerland: regional disparities and socioeconomic cleavages. International Political Science Review 8(4): 319-330.

Milner H and Ladner A (2006) Can PR voting serve as a shelter against declining turnout? Evidence from Swiss municipal elections. International Political Science Review 27: 29-45.

Norris P (2004) Electoral Engineering: Voting Rules and Political Behavior. Cambridge: Cambridge University Press.

Offe C and Fuchs S (2001) Schwund des Sozialkapitals? Der Fall Deutschland. In: Putnam RD (ed.) Gesellschaft und Gemeinsinn: Sozialkapital im internationalen Vergleich. Gütersloh: Verlag Stiftung Bertelsmann, 417-514.

Pateman C (1970) Participation and Democratic Theory. Cambridge: Cambridge University Press.

Radcliff B (1992) The welfare state, turnout, and the economy: a comparative analysis. American Political Science Review 86(2): 444-454.

Rac DW (1968) A note on the fractionalization of some European party systems. Comparative Political Studies 1: 413-418. 
Schaffer FC (2002) Might cleaning up elections keep people away from the polls? Historical and comparative perspectives. International Political Science Review 23: 69-84.

Schweizerische Arbeitskräfteerhebung (SAKE) (various years). Neuenburg: Bundesamt für Statistik.

Swiss Electoral Studies (Selects) (2004). Lausanne: Fors.

Siaroff A and Merer JWA (2002) Parliamentary election turnout in Europe since 1990. Political Studies 50: 916-927.

Snyder R (2001) Scaling down: the subnational comparative method. Studies in Comparative International Development 36(1): 93-110.

Staatssekretariat für Wirtschaft (SECO) (various volumes). Bern: Die Volkswirtschaft.

Statistisches Jahrbuch der Schweiz (various years). Neuenburg: Bundesamt für Statistik.

Sturm R (1992) Wahlbeteiligung. In: Schmidt MG (ed.) Lexikon der Politik, Band 3: Die westlichen Länder. Munich: CH Beck, 488-494.

Stutzer A (1999) Demokratieindizes für die Kantone der Schweiz. Working Paper No. 23. Zürich: Institute for Empirical Research in Economics.

De Tocqueville A ([1835]1994) Über die Demokratie in Amerika. Stuttgart: Reclam.

Vatter A (2002) Kantonale Demokratien im Vergleich. Entstehungsgründe, Interaktionen und Wirkungen politischer Institutionen in den Schweizer Kantonen. Opladen: Leske und Budrich.

Verba S and Nie NH (1972) Participation in America: Political Democracy and Social Equality. New York: Harper \& Row.

Wernli B (1998) Die Bestimmungsfaktoren der Wahlbeteiligung. Eine vergleichende Analyse von 10 Schweizer Kantonen. In: Kriesi H, Linder W and Klöti U (eds) Schweizer Wahlen 1995. Bern: Paul Haupt, 73-100.

White H (1980) A heteroskedasticity-consistent covariance matrix estimator and a direct test for heteroskedasticity. Econometrica 48: 817-838.

\section{Biographical Note}

Markus Freitag holds the chair of comparative politics at the University of Konstanz, Germany. He studied political science and economics at the universities of Heidelberg and Bern and was Assistant Professor at the Humboldt-University of Berlin. He has published on trust, social capital, direct democracy, comparative public policy and voter participation in the British Journal of Political Science, Comparative Political Studies, European Journal of Political Research, European Union Politics, Publius and West European Politics. ADDress: University of Konstanz, Department of Politics and Management, PO Box 84, D-78457 Konstanz, Germany [email: markus.freitag@uni-konstanz.de]. 